\title{
Self-acceptance Affects Attitudes in Caring for Sexual Function after Hysterectomy
}

Raden Khairiyatul Afiyah ${ }^{1,2 *} \mathbb{D}$, Chatarina Umbul Wahyuni ${ }^{3} \mathbb{D}$, Budi Prasetyo ${ }^{4}$, Mochammad Bagus Qomaruddin ${ }^{5}$, Ratna Yunita Sari ${ }^{2}$, Imamatul Faizah ${ }^{2}$ (D) Rusdianingseh Rusdianingseh (D), Fauziyatun Nisa ${ }^{6}$ iD, Firman Suryadi Rahman ${ }^{7}$ (D)

${ }^{1}$ Doctoral Student of Public Health, Faculty of Public Health, Universitas Airlangga, Mulyorejo, Surabaya, Indonesia; ${ }^{2}$ Department of Nursing, Nursing and Midwifery Faculty, Universitas Nahdlatul Ulama, Surabaya, Indonesia; ${ }^{3}$ Department of Epidemiology, Faculty of Public Health, Universitas Airlangga, Mulyorejo, Surabaya, Indonesia; ${ }^{4}$ Department of Obstetrics and Gynecology, Faculty of Medicine, Universitas Airlangga, Surabaya, Indonesia; ${ }^{5}$ Department of Health Promotion and Behavioral Sciences, Faculty of Public Health, Universitas Airlangga, Mulyorejo, Surabaya, Indonesia; ${ }^{6}$ Department of Midwifery, Nursing and Midwifery Faculty, Universitas Nahdlatul Ulama, Yogyakarta, Indonesia; ${ }^{7}$ Doctoral Student of Public Health, Universitas Airlangga, Surabaya, Indonesia

Edited by: Mirko Spirosk Citation: Afiyah RK, Wahyuni: CU, Prasetyo B, Romaruddin MB, Sari RY Faizah L, Rusdianingseh R Nisa F, Rahman FS. Self-acceptance Affects Attitudes in Caring for Sexual Function after Hysterectomy. Open Access Maced J Med Sci. 2021 Dec 06; 9(G):293-296. ttps://doi.org/10.3889/oamjms.2021.7568 Keywords: Self-acceptance; Affects; Attitudes; In caring Sexual function; Post hysterectomy "Correspondence: Raden Khairiyatul Afiyah, Department of Public Health, Faculty of Public Health, Universitas E-mail: er@unusesia. Received: 11-Oct-202 Revised: 25-Nov-202 Accepted: 26-Nov-202

Copyright: ๑ 2021 Raden Khairiyatul Afiyah, Chatarina Umbul Wahyuni, Budi Prasetyo, Ratna Yunita Sari Mochammad Bagus Qomaruddin, Ratna Yunita Sari, Imamatul Faizah, Rusdianingse Funding: This research did not receive any financi

support Competing Interests: The authors have declared that competing interests exist. Open Access: This is an open-access article distributed NonCommercial 4.0 International License (CC BY-NC 4.0)

\begin{abstract}
BACKGROUND: A comprehensive understanding of several approaches, both pharmacological and nonpharmacological, is needed to reduce sexual function problems after hysterectomy. As one example, the research of Rawland et al. (2015) and that study found that cognitive, affective, motivational, behavioral, self-efficacy, and sexual acceptance responses could potentially play an important roles in the assessment of appropriate care. However, in general, there is no research that explains that self-acceptance can affect attitudes.

AIM: This study aims to analyze the correlation between self-acceptance with attitudes toward caring for sexual function after hysterectomy.

METHODS: The data measured were self-acceptance and attitudes toward treatment of sexual function after hysterectomy which was obtained from post-hysterectomy women. Data on self-acceptance using the Selfacceptance - Scale for Persons with Early Blindness (SAS-EB) questionnaire and data on attitudes toward caring for sexual function were made by researchers using references from the theory planned of behavior (TPB) (Alshawish et al., 2020). Statistical analysis used was Chi-square to analyze self-acceptance with attitudes to caring for sexua function after hysterectomy.

RESULTS: This study found the importance of self-acceptance in determining attitudes toward caring for sexual function after hysterectomy. A person's positive attitude will affect behavior to treat sexual function after hysterectomy. CONCLUSION: In general, this study proves that self-acceptance is related to attitudes to caring for sexual function after hysterectomy.
\end{abstract}

\section{Introduction}

Comprehensive understanding of several approaches and methods both pharmacologically and non-pharmacologically is needed in improving sexual function after hysterectomy [1]. Pharmacological methods are needed to reduce hormonal-related problems [2]. While non-pharmacology is needed to improve health and what is very important is a psychological approach because it can affect especially attitudes and behavior [3].

Several studies on self-acceptance related to several types of disorders have been carried out. Self-efficacy and self-acceptance and the study found that the importance of assessing the need for sexual self-efficacy is an important factor as part of the assessment of sexuality in postmenopausal women [4].
Bak [5] conducted a study on the relationship of sexual dysfunction with depression and acceptance of disease in women and men with type 2 diabetes mellitus and the study found that sexual disorders in patients with type 2 diabetes showed a correlation with the occurrence of depression and acceptance of the disease. Rawland [6] conducted a study on self-efficacy as a relevant construct in understanding sexual response and dysfunction and the study found that cognitive, affective, motivational and behavioral responses, and sexual self-efficacy have the potential to play an important role in the assessment of appropriate care effective for sexual problems. A study on self-acceptance of stuttering the study found that individual differences in low unconditional self-acceptance were detrimental to well-being and, in some cases, could lead to mental health problems and mental disorders [7]. The study found that low 
unconditional self-acceptance is detrimental to wellbeing and, in some cases, can lead to mental health problems and mental disorders.

Although research on solutions to sexual dysfunction after hysterectomy has been carried out, in general, the above research shows that so far no one has explained the importance of selfacceptance in influencing attitudes. Several studies explain that self-efficacy and sexual self-acceptance are important factors as part of the assessment of sexuality in postmenopausal women. Bak [5] explained that sexual disorders in patients with type 2 diabetes showed a correlation with the occurrence of depression and acceptance of the disease. Rawland6 explain that cognitive, affective, motivational and behavioral responses, and sexual self-efficacy have the potential to play an important role in the assessment of effective treatments for sexual problems.

The above discussion shows that selfacceptance as a new approach to the treatment of sexual function after hysterectomy is important for treatment and is indispensable. Therefore, this study aims to propose a new model based on a psychological approach that can improve the health of sexual function after hysterectomy.

\section{Methods}

Data obtained from women after hysterectomy as many as 102 people who live in Surabaya. The data obtained are based on data from the Hospital of Islam Jemursari Surabaya and the Hospital of Islam A yani Islam Surabaya. Data on self-acceptance used the SAS-EB (Self-acceptance - Scale for Persons with Early Blindness) questionnaire and data on attitude caring for sexual function were made by researchers using references from the theory planned of behavior (TPB) [8]. Data analysis was carried out by Chi-square statistical test with significant $p<0.05$. The results of the analysis can be concluded that if the $p<0.05$ then $\mathrm{HO}$ is rejected, meaning that there is a correlation between self-acceptance and attitudes to caring for sexual function after hysterectomy and if the $p>0.05$, then $\mathrm{HO}$ is accepted, meaning there is no correlation between self-acceptance with attitudes to caring for sexual function after hysterectomy.

\section{Results}

\section{Respondents characteristics}

Table 1 shows that the most of the 102 respondents $(54.9 \%)$ were in early adulthood. Almost half $(46.1 \%)$ of the education levels are highly educated. The parity almost all $(83.3 \%)$ is multipara and the knowledge almost half $(39.2 \%)$ is high

Table 1: Frequency distribution of respondent characteristics

\begin{tabular}{|c|c|c|c|c|c|}
\hline \multirow[t]{2}{*}{ Characteristics } & \multicolumn{2}{|c|}{$\begin{array}{l}\text { Respondent } \\
(102)\end{array}$} & \multirow[t]{2}{*}{ Characteristics } & \multicolumn{2}{|c|}{$\begin{array}{l}\text { Respondent } \\
\mathrm{n}(102)\end{array}$} \\
\hline & $f$ & $\%$ & & $f$ & $\%$ \\
\hline Age (years) & & & Parity & & \\
\hline Late adulthood (36-45) & 46 & 45.1 & Primipara & 18 & 17.7 \\
\hline Early adolescence $(46-55)$ & 56 & 54.9 & Multipara & 84 & 82.3 \\
\hline Education & & & Knowledge & & \\
\hline Basic & 20 & 19.6 & Low & 30 & 29.4 \\
\hline Intermediate & 35 & 34.3 & Medium & 40 & 39.2 \\
\hline High & 47 & 46.1 & High & 32 & 31.4 \\
\hline
\end{tabular}

Table 2 shows that almost half of the 102 respondents $(44.1 \%)$ are intermediate self-acceptance and almost half $(49.1 \%)$ of the attitude to take care for sexual function after hysterectomy were intermediate.

Table 2: Self-acceptance and attitude to care for sexual function after hysterectomy

\begin{tabular}{lll}
\hline Characteristics & \multicolumn{2}{l}{ Respondent n (102) } \\
\cline { 2 - 3 } & $\mathrm{F}$ & $\%$ \\
\hline Self-acceptance & 22 & 21.6 \\
$\quad$ Lack & 45 & 44.1 \\
Intermediate & 35 & 34.3 \\
$\quad$ Good & & \\
Attitudes in caring for sexual function & 23 & 22.5 \\
$\quad$ Lack & 50 & 49.1 \\
Intermediate & 29 & 28.4 \\
$\quad$ Good & & \\
\hline
\end{tabular}

Table 3 shows that of the 45 respondents who with self-acceptance most $(55.6 \%)$ of the attitude to take care of sexual function after hysterectomy are intermediate. The results of cross-tabulation the correlation between self-acceptance with attitudes toward caring for sexual function after hysterectomy were analyzed using the Chi-square test, the result was $p=0.007$ which means that there is a correlation between self-acceptance with attitudes toward caring for sexual function after hysterectomy.

Table 3: Correlation between self-acceptance with attitudes toward caring for sexual function after hysterectomy

\begin{tabular}{|c|c|c|c|c|c|c|c|c|}
\hline \multirow[t]{2}{*}{ Variable } & \multicolumn{8}{|c|}{ Attitudes in caring for sexual function } \\
\hline & \multicolumn{2}{|c|}{ Lack } & \multicolumn{2}{|c|}{ Intermediate } & \multicolumn{2}{|c|}{ Good } & \multicolumn{2}{|l|}{ Total } \\
\hline Self-acceptance & $f$ & $\%$ & $f$ & $\%$ & $f$ & $\%$ & $f$ & $\%$ \\
\hline Lack & 5 & 22.7 & 10 & 45.5 & 7 & 31.8 & 22 & 21.6 \\
\hline Intermediate & 9 & 20 & 25 & 55.6 & 11 & 24.4 & 45 & 44.1 \\
\hline Good & 9 & 25.7 & 15 & 42.9 & 11 & 31.4 & 35 & 34.3 \\
\hline $\mathrm{p}$ & & & & & & & 0.007 & \\
\hline
\end{tabular}

\section{Discussion}

The results showed that there was a correlation between self-acceptance with attitudes toward caring for sexual function after hysterectomy with $p$ value $=$ 0.007. Self-acceptance has a very big influence on how a person will behave in dealing with post-hysterectomy problems, namely, sexual function. Self-acceptance according to the Chaplin [9] is an attitude that is basically satisfied with oneself, one's qualities and talents, and recognition of one's shortcomings [9]. Self-acceptance 
is manifested by being able to recognize self-worth as a person. Self-acceptance is the basis of an attitude of selfesteem and a feeling of comfort in oneself regardless of faults and weaknesses [10]. Self-acceptance will be easily realized if in a person there is a belief that he can do the best for himself [11]. Self-acceptance is very important for a woman after a hysterectomy, especially with regard to sexual function. Self-acceptance will form confidence to take the best action for yourself and your partner [12]. Self-acceptance in post-hysterectomy women is influenced by several important factors, namely, family environmental factors, personal factors, and family factors [13]. Self-acceptance can shape attitudes, norms, and beliefs as well as the ability to control behavior so that it will influence someone to take an action. The self-acceptance model can increase self-confidence; self-ability to interpret life well so that post-hysterectomy sexual function can be resolved and quality of life is not disturbed [14], [15].

Sexual function problems are a common effect of hysterectomy. These problems have an impact on fulfilling sexual needs with partners so that appropriate action is needed to improve health status comprehensively which includes physical, psychological, social, and spiritual care [16]. Comprehensive treatment to improve the health of sexual function after hysterectomy is not easy to implement, because it requires a conductive psychological condition, namely, the ability to accept the present imperfections. In this case, support from spouse and family is needed. This is in accordance with Thakar's research which states that post-hysterectomy selfacceptance is influenced by psychological conditions, namely, the presence of social support (husband, family, and health workers). Psychological factors also affect self-acceptance after hysterectomy because they positively believe that hysterectomy does not have a negative impact on life with their partner [17]. When a person is able to accept himself from sexual function problems, then someone will realize to take an action so that this can influence a person to behave in maintaining healthy sexual function after hysterectomy [17].

Several factors that influence self-acceptance in treating sexual function after hysterectomy are age, education, number of children, and knowledge about hysterectomy. Based on Table 1, the results show that the most $(54.9 \%)$ are in early adulthood; this shows that the most of the respondents are entering their productive period. At that age, a person is at physical and psychological maturity so that everything that happens in his life requires careful thought to make a decision [18]. At that age, psychological conditions related to the maturity of married life are at a good level, thus issues related to sexual function will be discussed together with partners so that they will find the best decision for sexual life after hysterectomy [19].

Based on Table 1, almost half $(46.1 \%)$ of the respondents' education have higher education. The high level of education of the respondents is because the most of the respondents live in big cities where their educational life is modern, there are many universities that are diverse and of high quality, thus the population is competing to pursue the best education to improve their standard of living. Education affects a person in seeking information about everything that happens in his life so that when a person faces life's problems it will be easier to find the best solution [20]. A person's attitude to do something is closely related to the knowledge possessed and many experts argue that knowledge is directly proportional to one's education.

Based on Table 1, almost all (82.7\%) children born are the number of children born alive more than one. The more children, the better the way a person adapts to unfavorable conditions. The number of children more than one allows a person not to really want to have more children because a hysterectomy will result in a woman being unable to reproduce [21]. The number of children who have been born affects a person in accepting himself after a hysterectomy because of the assumption that the more children born, the more perfect a woman is [22].

Based on Table 1, almost half (39.2\%) of the respondents' knowledge about hysterectomy had a moderate level of knowledge. This is because knowledge about hysterectomy is an uncommon knowledge that is easily conveyed by anyone but requires people who have knowledge in this field to explain information about hysterectomy and its treatment [23], [24], [25]. This is in accordance with the research of Thompson, et al. 2016 that health workers can provide health education about hysterectomy and its treatment to patients, husbands, and families during pre- and post-surgery.

\section{Conclusions}

The purpose of this study was to determine the correlation between self-acceptance with attitudes toward caring for sexual function after hysterectomy. This study found the importance of self-acceptance in determining attitudes to caring for sexual function after hysterectomy. The nurse's role in this case is as an educator, namely, providing information about hysterectomy and its treatment. Suggestions for further researchers are to add qualitative methods, variables, and increase the number of respondents.

\section{Acknowledgement}

We would like to thank the Universitas Nahdlatul Ulama Surabaya for their friendly support. 


\section{References}

1. Safarinejad MR, Shafiei N, Safarinejad S. Quality of life and sexual functioning in young women with early-stage breast cancer 1 year after lumpectomy. Psychooncology. 2013;22(6):1242-8. https://doi.org/10.1002/pon.3130 PMid:22777952

2. Danesh M, Hamzehgardeshi Z, Moosazadeh M, ShabaniAsrami $F$. The effect of hysterectomy on women's sexual function: A narrative review. Med Arch. 2015;69(6):387. https:// doi.org/10.5455/medarh.2015.69.387-392 PMid:26843731

3. Vasile C. An evaluation of self-acceptance in adults. Proc Soc Behav Sci. 2013;78:605-9.

4. Metz ME, Epstein NB, McCarthy B. Cognitive-Behavioral Therapy for Sexual Dysfunction. London, United Kingdom: Routledge; 2017.

5. Bąk E, Marcisz C, Krzemińska S, Dobrzyn-Matusiak D, Foltyn A, Drosdzol-Cop A. Relationships of sexual dysfunction with depression and acceptance of illness in women and men with Type 2 diabetes mellitus. Int J Environ Res Public Health. 2017;14(9):1073. https://doi.org/10.3390/ijerph14091073 PMid:28926936

6. Rowland DL, van Lankveld JJ. Anxiety and performance in sex, sport, and stage: Identifying common ground. Front Psychol. 2019;10:1615. https://doi.org/10.3389/fpsyg.2019.01615 PMid:31379665

7. Huang Y, Wu R, Wu J, Yang Q, Zheng S, Wu K. Psychological resilience, self-acceptance, perceived social support and their associations with mental health of incarcerated offenders in China. Asian J Psychiatr. 2020;52:102166. https://doi. org/10.1016/j.ajp.2020.102166

PMid:32447270

8. Alshawish E, Qadous S, Yamani MA. Experience of Palestinian women after hysterectomy using a descriptive phenomenological study. Open Nursing J. 2020;14:74-9.

9. Sutton P. Past, present, and future of hysterectomy. J Minim Invasive Gynecol. 2020;17(4):421-35. https://doi.org/10.1016/j. jmig.2010.03.005 PMid:20621006

10. Moshki M, Mohammadzadeh F, Dehnoalian A. The effectiveness of a group-based educational program on the self-efficacy and self-acceptance of menopausal women: A randomized controlled trial. J Women Aging. 2018;30(4):310-25. https://doi. org/10.1080/08952841.2017.1366753 PMid:28901839

11. Overholser J, Dimaggio G. Struggling with perfectionism: When good enough is not good enough. J Clin Psychol. 2020;76(11):2019-27. https://doi.org/10.1002/jclp.23047 PMid:32860445

12. Metz ME, Epstein N, Mccarthy B. Cognitive-Behavioral Therapy for Sexual Dysfunction. London, United Kingdom: Routledge; 2017.
13. Black-Kutner R. Self-Acceptance, Partner-Acceptance, and Forgiveness Relating to Marital Satisfaction. Hempstead: Hofstra University; 2020

14. Afiyah RK, Wahyuni CU, Prasetyo B, Winarno DD. Recovery time period and quality of life after hysterectomy. J Public Health Res. 2020;9(2):1837. https://doi.org/10.4081/jphr.2020.1837 PMid:32728576

15. Meher T, Sahoo H. Regional pattern of hysterectomy among women in India: Evidence from a recent large scale survey. Women Health. 2020;60(5):585-600. https://doi.org/10.1080/03 630242.2019 .1687634

PMid:31718517

16. Thomas HN, Hamm M, Hess R, Thurston RC. Changes in sexual function among midlife women: "I'm older... and I'm wiser.". Menopause. 2018;25(3):286-92. https://doi.org/10.1097/ GME.0000000000000988 PMid:29088016

17. Tutuncu B, Yildiz H. The influence on women's sexual functions of education given according to the PLISSIT model after hysterectomy. Proc Soc Behav Sci. 2012;47:2000-4.

18. Rew L, Thompson S, Brown A, Seo E. An intervention to enhance psychological capital in homeless females: Preliminary findings. J Adolesc Health. 2014;54(2):S13.

19. Elmoneim EF, Ghonemy GE, Hassan NI. Effect of roy adaptation model on sexual function and spousal support among women after total hysterectomy. IOSR J Nursing Health Sci. 2017;6(2):130-40.

20. Silverstein RG, Brown AC, Roth HD, Britton WB. Effects of mindfulness training on body awareness to sexual stimuli: Implications for female sexual dysfunction. Psychosom Med. 2011;73(9):817-25. https://doi.org/10.1097/ PSY.0b013e318234e628 PMid:22048839

21. Brotto LA, Smith KB. Applications of mindfulness in the treatment of women's sexual dysfunction. The Wiley Blackwell Handbook of Mindfulness. New York, United States: John Wiley \& Sons; 2014. p. 864-80.

22. Sarhan D, Mohammed GF, Gomaa AH, Eyada MM. Female genital dialogues: Female genital self-image, sexual dysfunction, and quality of life in patients with vitiligo with and without genital affection. J Sex Marital Ther. 2016;42(3):267-76. https://doi.org/ 10.1080/0092623X.2015.1010678

PMid:25650731

23. McEachan RR, Conner M, Taylor NJ, Lawton RJ. Prospective prediction of health-related behaviours with the theory of planned behaviour: A meta-analysis. Health Psychol Rev. 2011;5(2):97-144.

24. Rahman FS, Martiana T. Pregnancy disorders in female workers at the industrial area of Sidoarjo, Indonesia. J Public Health Res. 2020;9(2):1824. https://doi.org/10.4081/jphr.2020.1824 PMid:32728568

25. Rahman FS, Martiana T. Analysis of factors related to maternal health in female workers in the industrial area of Sidoarjo, Indonesia. J Public Health Afr. 2019;10(S1):41-4. 